\title{
Evolutionary origin and systematic position of Euphorbia normannii (Euphorbiaceae), an intersectional hybrid and local endemic of the Stavropol Heights (Northern Caucasus, Russia)
}

\author{
Božo Frajman ${ }^{1}$ (1) . Dmitry Geltman²
}

Received: 9 May 2020 / Accepted: 7 January 2021 / Published online: 22 February 2021

(c) The Author(s) 2021

\begin{abstract}
The Caucasus is one of the richest areas in the world in terms of animal and plant diversity, harbouring 6400 plant species. As a part of the Northern Caucasus, the Stavropol Heights are renowned for their local endemism, highlighted by six species of flowering plants endemic to this area. One of them is the annual species Euphorbia normannii, described in 1891, but with uncertain taxonomic position. We here used nuclear ribosomal internal transcribed spacer and plastid $\operatorname{trn} \mathrm{T}-\operatorname{trn} \mathrm{F}$ sequences to infer the phylogenetic position of E. normannii. The nuclear data inferred its position within E. sect. Myrsiniteae, whereas the plastid data placed it within E. sect. Pithyusa, thus indicating a hybrid origin. Relative genome size (RGS) data indicate that $E$. normannii has the highest RGS compared to three other annual species belonging to both sections (E. aleppica, E. gaillardotii and E. falcata). Our data are inconclusive whether E. normannii is of allopolyploid or homoploid hybrid origin, or whether later hybridisation and plastid capture from E. sect. Pithyusa was responsible for the incongruent phylogenetic signal. Morphologically, E. normannii is distinct, as are all three before-mentioned annuals, which fall in predominately perennial sections. However, the species most similar to E. normannii is E. falcata from E. sect. Pithyusa and therefore we propose inclusion of E. normannii in this section.
\end{abstract}

Keywords Caucasus $\cdot$ Endemism $\cdot$ Genome size $\cdot$ Morphology $\cdot$ Phylogenetics $\cdot$ Taxonomy

\section{Introduction}

Euphorbia L. (Euphorbiaceae) is one of the largest genera of flowering plants. Most of its species occurring in temperate Eurasia belong to E. subgen. Esula Pers., which contains roughly 480 species and represents the earliest diverging subgenus within Euphorbia. In the most recent taxonomic revision, 21 sections were recognised within this subgenus, based mainly on nuclear and plastid DNA sequence phylogenies (Riina et al. 2013). Several species, for which phylogenetic data were not available, were classified into sections

Handling Editor: Andreas Tribsch.

Božo Frajman

bozo.frajman@uibk.ac.at

1 Department of Botany, University of Innsbruck, Sternwartestrasse 15, 6020 Innsbruck, Austria

2 Komarov Botanical Institute of the Russian Academy of Sciences, 2 Prof. Popov Street, St. Petersburg, Russia 197376 based on morphological grounds. One of these species is E. normannii Schmalh. ex Lipsky, which was described by Lipsky (1891) with a very short diagnosis in Russian. During his exploration of the Northern Caucasus in 1889-1890, he collected an unusual annual Euphorbia near Nevinnomysskaya village (now the town of Nevinnomyssk). The collections appeared to be identical with specimens collected in 1879 and 1883 in the vicinity of Stavropol by A. Normann and "kept together with E. falcata" in his herbarium. However, "I. F. Schmalhausen proposed to distinguish [these specimens] as a separate species E. normannii" (Lipsky 1891). One year later, Schmalhausen (1892) published a detailed Latin description of E. normannii along with an illustration of its seeds and listed three localities, all from the Stavropol Heights (Stavropol'skaya vozvyshennost') in the Northern Caucasus in Russia.

The Caucasus is one of the richest areas in the world in terms of animal and plant diversity and is considered one of the 25 Global Biodiversity Hotspots of high conservation priority (Myers et al. 2000). It harbours 6400 plant species (Mittermeier et al. 2005) of which over 2700 taxa are 
endemic to this area (Solomon et al. 2014). Species diversity and endemism are exceptionally high for a temperate zone and relate to the geographic position of the Caucasus at the junction of two distinct biogeographic regions, the EuroSiberian and Irano-Turanian (Mittermeier et al. 2005). Even if most endemic species occur in the Greater and Lesser Caucasus (Mittermeier et al. 2005), the Stavropol Heights in the north of the main Caucasian chain are also renowned for their local endemism (Menitsky 2004; Ivanov et al. 2010).

The formation of the Stavropol Heights began in the Late Miocene as a peninsula of the south coast of the Paratethys (Popov et al. 2004), but its area expanded later (Panina 2009) and nowadays consists mainly of clay, limestone and sandstones. The plateau, which is on average 300 to $600 \mathrm{~m}$ high, with the highest summit (Strizhament hill) reaching $831 \mathrm{~m}$, is intertwined with wide river valleys and streams. The natural vegetation of this area with temperate continental climate consists mainly of steppes and localised deciduous forests, which have been largely transformed to agricultural landscapes. Besides E. normannii, Ivanov et al. (2010) listed five angiosperms as endemic to the Stavropol Heights, namely Erodium stevenii M. Bieb., Euphorbia aristata Schmalh., Hieracium stauropolitanum Üksip, Psephellus annae Galushko and Vincetoxicum stauropolitanum Pobed. Most of these species have no close relatives in the Caucasian flora (Ivanov et al. 2010).

Prokhanov (1949) included E. normannii in Euphorbia subgen. Paralias (Raf.) Prokh. sect. Cymatospermum Prokh. subsect. Oleraceae Prokh. and considered it to be "closely related to the common E. falcata L., from which it is easily distinguished by the seeds with two rows of pits at each face and not one". This section, for which later the name E. sect. Peplus Lázaro got established (Prokhanov 1964), included annuals with various ornamentation of seed surface. However, Frajman and Schönswetter (2011) showed that $E$. sect. Cymatospermum was polyphyletic and its representatives were included in eight different sections by Riina et al. (2013). Euphorbia falcata was thus included in E. sect. Pithyusa (Raf.) Lázaro based on its phylogenetic position, whereas E. normannii, for which no phylogenetic data existed, was placed in E. sect. Arvales (Geltman) Geltman on morphological grounds. Euphorbia normannii shares free styles and in cross section subquadrangular, irregularly tuberculate-rugulose seeds with $E$. arvalis Boiss. $\&$ Heldr. and E. franchetii B. Fedtsch., which were, based on DNA sequence data, included in E. sect. Arvales. However, based on ITS sequence data (A. Kryukov, unpublished) Geltman (2015) suggested that E. normannii should rather be included in E. sect. Myrsiniteae. Euphorbia sect. Myrsiniteae and $E$. sect. Pithyusa include 14 and 50, mostly perennial, but also one (E. aleppica L.) and two (E. falcata and E. gaillardotii Boiss. \& Blanche) annual species, respectively. Both sections share several morphological characteristics, like being glaucous and having palmate leaf venation, and were resolved as sisters by the plastid sequence data, whereas the relationships between them based on the ITS sequences remained unresolved, and E. sect. Myrsiniteae was rather inferred as sister to $E$. sect. Lagascae Lázaro (Riina et al. 2013). The placement of annual E. aleppica in E. sect. Myrsiniteae and of E. falcata and E. gaillardotii in $E$. sect. Pithyusa was very surprising, as these annuals are morphologically very divergent from perennials included in these sections (Frajman and Schönswetter 2011; Pahlevani et al. 2011; Riina et al. 2013).

The aim of this paper is to infer the phylogenetic position of E. normannii using nuclear ribosomal ITS and plastid $\operatorname{trn} \mathrm{T}-\operatorname{trn} \mathrm{F}$ sequences, and to provide a hypothesis of its hybrid origin based on the inferred phylogenies. In addition, we compare morphological characteristics and relative genome size (RGS) data of E. normannii with other annual species from E. sect. Myrsiniteae and E. sect. Pithyusa and provide a revised taxonomic treatment including the species description of $E$. normannii, updated compared to the one provided by Schmalhausen (1892).

\section{Materials and methods}

\section{Plant material}

Plant material for RGS estimation, molecular and morphometric analyses of E. normannii was sampled from herbarium vouchers deposited at LE, whereas molecular and RGS analyses of other species were based on silica gel dried leaf material (Online Resource 1). In total, three specimens of $E$. normannii from three different localities were studied phylogenetically, for one specimen RGS was estimated and 16 were included in the morphological analyses. (For details, see "Specimens studied" in the Taxonomic treatment.) For morphological characters of E. normannii and of closely related/morphologically similar E. aleppica, E. falcata and E. gaillardotii, several specimens deposited at LE were studied.

\section{DNA extraction, sequencing and analyses of sequence data}

Extraction of total genomic DNA and sequencing were performed as described by Frajman and Schönswetter (2011), with the exception that the sequencing was carried out at Eurofins Genomics (Ebersberg, Germany). Contigs were assembled, edited and sequences aligned using Geneious Pro 5.5.9 (Kearse et al. 2012). Base polymorphisms were coded using NC-IUPAC ambiguity codes. GenBank numbers of sequences are given in Online Resource 1. The sampling of species was based on 
preliminary phylogenetic analyses, in which E. normannii was added to the alignments of Frajman and Schönswetter (2011). As E. normannii was shown to belong either to E. sect. Myrsiniteae or to E. sect. Pithyusa, we included several published sequences from these sections and sequenced some additional accessions, to achieve a representative taxonomic and phylogenetic coverage of both sections, mostly based on phylogenies inferred by Riina et al. (2013). As E. sect. Lagascae was inferred as sister to $E$. sect. Myrsiniteae by ITS sequences, we also included this section in our ITS phylogenetic analyses, but not in the plastid analyses, as in the plastid tree the former section was inferred as distantly related to $E$. sect. Myrsiniteae and E. sect. Pithyusa (Riina et al. 2013). Likewise, we did not include E. sect. Arvales in our analyses, as it is only distantly related to $E$. sect. Myrsiniteae and $E$. sect. Pithyusa (Riina et al. 2013). However, we included five species from E. sect. Helioscopia to root the trees (see Online Resource 1 for details). In total, seven ITS and five $\operatorname{trn} \mathrm{T}-\operatorname{trn} \mathrm{F}$ sequences were generated in this study and 36 ITS and $33 \operatorname{trn} \mathrm{T}-\operatorname{trn} \mathrm{F}$ sequences were included from previous studies (Frajman and Schönswetter 2011, 2017; Riina et al. 2013; Falch et al. 2019). GenBank numbers are given in Online Resource 1, and the ITS and plastid alignments are available in Online Resource 2 and 3, respectively.

Maximum parsimony (MP) and MP bootstrap (MPB) analyses were performed using PAUP 4.0b10 (Swofford 2002). The most parsimonious trees were searched for heuristically with 1000 replicates of random sequence addition, TBR swapping and MulTrees on. The swapping was in the case of ITS performed on a maximum of 1000 trees (nchuck $=1000$ ). All characters were equally weighted and unordered. The data set was bootstrapped using full heuristics, 1000 replicates, TBR branch swapping, MulTrees option off and random addition sequence with five replicates.

Bayesian analyses were performed using MrBayes 3.2.1 (Ronquist et al. 2012) applying the GTRG substitution model proposed by the Akaike information criterion implemented in MrAIC.pl 1.4 (Nylander 2004). Values for all parameters, such as the shape of the gamma distribution, were estimated during the analyses. The settings for the Metropolis-coupled Markov chain Monte Carlo process included four runs with four chains each (three heated ones using the default heating scheme), run simultaneously for 10,000,000 generations each, sampling trees every 1000th generation using default priors. The posterior probabilities (PP) of the phylogeny and its branches were determined from the combined set of trees, discarding the first 1001 trees of each run as burn-in. In addition, a NeighborNet was produced with ITS sequences using SplitsTree4 12.3 (Huson and Bryant, 2006).

\section{Relative genome size measurements}

RGS was measured for one specimen of $E$ normannii, three populations of E. aleppica (E. sect. Myrsiniteae), twelve populations of E. falcata and one of E. gaillardotii (E. sect. Pithyusa), as well as two populations of E. phymatosperma (E. sect. Lagascae; see Online Resource 1 for details). We only included the annual species from the sections closely related to $E$. normannii, as the perennials for which RGS data exist are phylogenetically divergent from E. normannii. The perennials have RGS at least three times higher from E. aleppica in E. sect. Myrsiniteae (Falch et al. 2019) and ranging between the values recorded for E. falcata (in case of E. niciciana (Borbás) Rech. fil. and E. seguieriana Necker; Frajman et al. 2019) and the values that are about five times higher in $E$. sect. Pithyusa (Frajman, unpublished data).

The RGS was estimated with a CyFlow space flow cytometer (Partec, GmbH, Münster, Germany) using 4',6-diamidino-2-phenylindole (DAPI) and the reference standard Bellis perennis $\mathrm{L}$. ( $2 \mathrm{C}=3.38 \mathrm{pg}$; Schönswetter et al. 2007) following Suda and Trávníček (2006) and modifications described by Cresti et al. (2019). The RGS was calculated as the ratio between the values of the mean relative fluorescence of the sample and the standard.

\section{Morphological analyses and geographical distribution data}

The morphological description of E. normannii was produced based on 16 herbarium specimens deposited in LE. Plant height, stem, leaf and some of the raylet leaf characters, number and length of axillary and terminal rays as well as number of branchings of rays were scored manually. Raylet leaf, cyathium, capsule and seed characters were studied and measured using a stereo microscope Stemi 305 (Carl Zeiss) with measuring ruler. Photographs of seeds were taken using a stereo microscope SreREO Lumar.V12 (Carl Zeiss), with a camera AxioCam MRc5. In addition, morphological characters of E. aleppica, E. falcata and E. gaillardotii were studied on herbarium specimens deposited at LE and supplemented with the species' descriptions by Prokhanov (1949) and Radcliffe-Smith (1982). The geographical distribution data of E. normannii were extracted from the herbarium labels of the specimens deposited in LE and MW.

\section{Results}

\section{ITS and plastid phylogenies}

The ITS alignment was 731 characters long, and 187 characters $(25.6 \%)$ were parsimony informative. Homoplasy index was 0.36 (0.42 after exclusion of uninformative 
characters), and the retention index was 0.85 . In total, 67,688 most parsimonious trees were found and their length was 606. Bayesian and maximum parsimony reconstructions resulted in congruent topologies (Fig. 1a). Euphorbia normannii was positioned within E. sect. Myrsiniteae (PP 1, MPB 96\%), as sister to the rest of the taxa, which formed a clade (PP 0.98, MPB 93\%), in which E. aleppica was sister to other taxa. Euphorbia sect. Lagascae was sister to E. sect. Myrsiniteae (PP 1, MPB $82 \%$ ), and their sister was E. sect. Pithyusa (PP 1, MPB 97\%), in which annual E. falcata and E. gaillardotii were included. The NeighborNet (Fig. 1b) revealed several conflicting splits. Euphorbia normannii was positioned along a long split with other species of E. sect. Myrsiniteae, from which it was clearly divergent, and shared a common short split with the species of E. sect. Pithyusa, of which the annual E. falcata was closest to E. normannii.
Euphorbia sect. Lagascae was intermediate between E. sect. Helioscopia and E. sect. Myrsiniteae.

The $\operatorname{trn} \mathrm{T}-\operatorname{trn} \mathrm{F}$ alignment was 1676 characters long; 91 characters (5.4\%) were parsimony informative. Homoplasy index was 0.07 (0.09 after exclusion of uninformative characters), and the retention index was 0.98 . Sixty-six most parsimonious trees were found, and their length was 154 . Bayesian and maximum parsimony reconstructions resulted in congruent topologies (Fig. 2). Euphorbia normannii was positioned within E. sect. Pithyusa (PP 1, MPB 94\%), as sister of most of the perennial taxa (PP 0.99, MPB 70\%), with exception of E. cassia Boiss. and E. pithyusa L., which were, along with the annual E. falcata, positioned in a basal polytomy; E. gaillardotii was in the same clade with E. cassia (PP 1, MPB 85\%). Euphorbia sect. Pithyusa was sister (PP 1, MPB $100 \%$ ) to E. sect. Myrsiniteae (PP 1, MPB 98\%), in which the annual E. aleppica was sister to the perennial taxa.

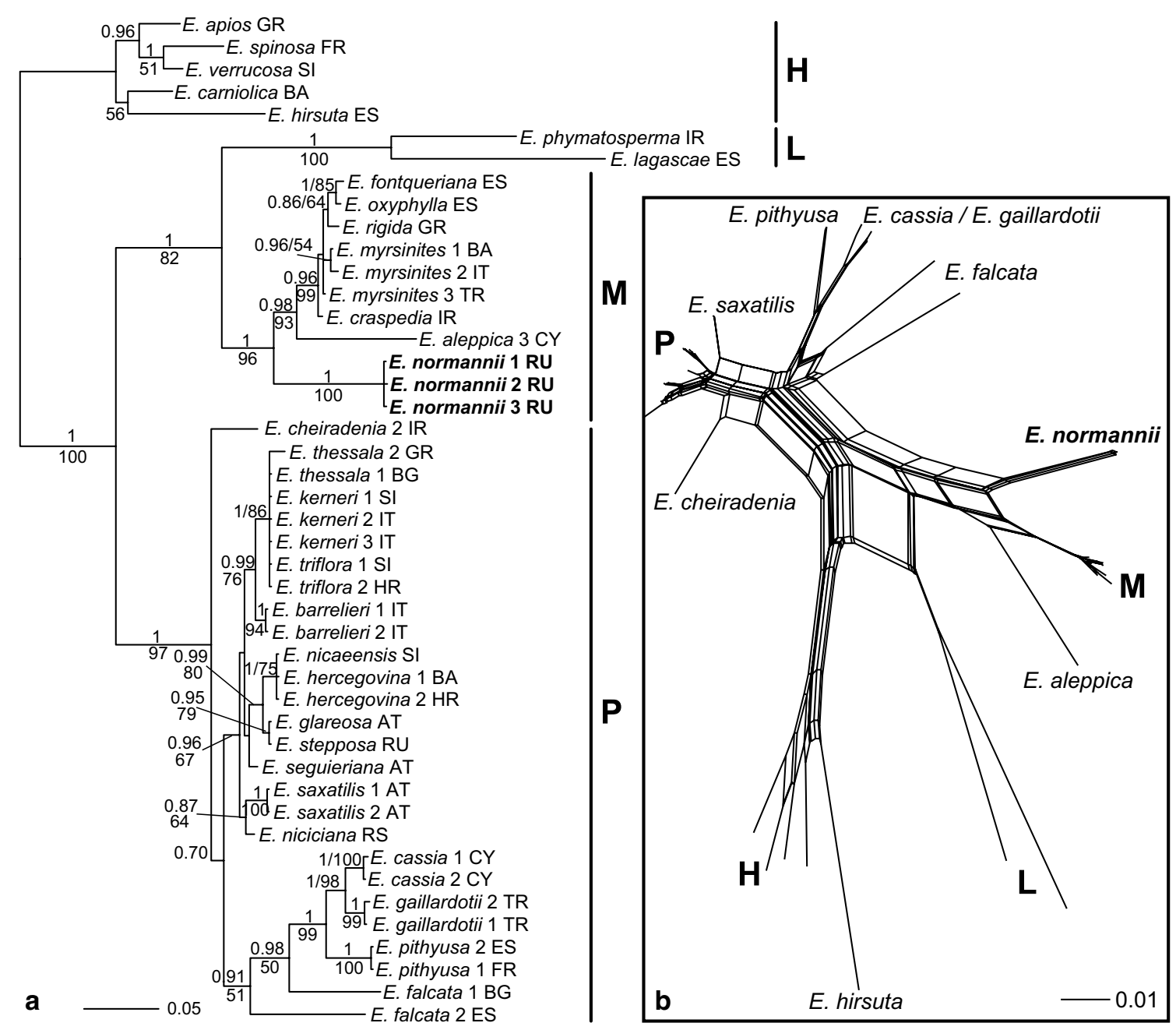

Fig. 1 Bayesian consensus phylogram (a) and NeighborNet (b) inferred from ITS sequences, showing the phylogenetic position of Euphorbia normannii, including different species from the sections E. sect. Helioscopia (H), E. sect. Lagascae (L), E. sect. Myrsiniteae

(M) and E. sect. Pithyusa (P). Numbers above branches in a are posterior probabilities above 0.65 ; those below branches maximum parsimony bootstrap values. Population numbers correspond to Online Resource 1 . Two-letter country codes follow the accession names 


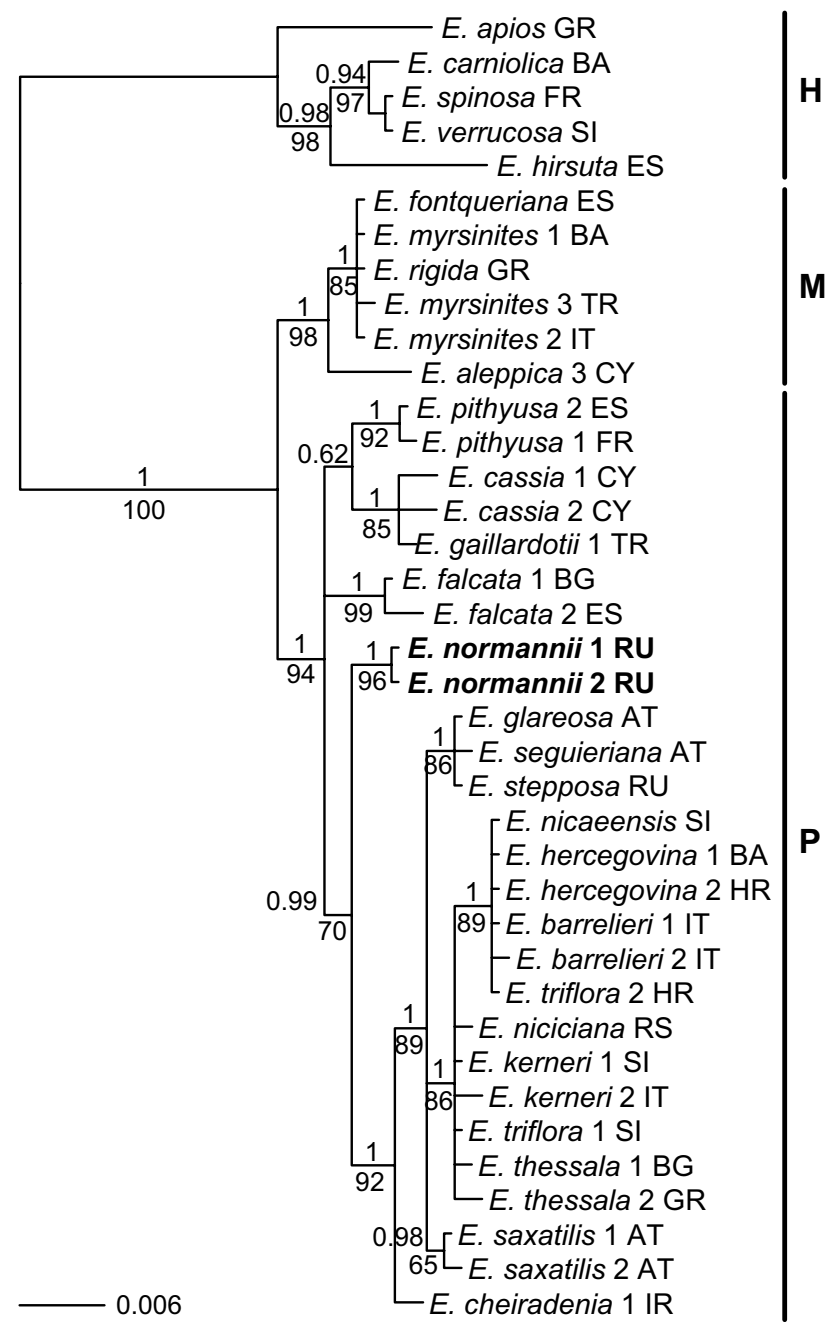

Fig. 2 Bayesian consensus phylogram inferred from plastid trnT-trnF sequences showing the phylogenetic position of Euphorbia normannii, including different species from the sections E. sect. Helioscopia $(\mathrm{H})$, E. sect. Myrsiniteae (M) and E. sect. Pithyusa (P). Numbers above branches are posterior probabilities; those below branches maximum parsimony bootstrap values. Population numbers correspond to Online Resource 1. Two-letter country codes follow the accession names

\section{Relative genome size}

The RGS of E. aleppica ranged between 0.334 (population 1) and 0.373 (population 3), that of E. falcata between 0.450 (population 3) and 0.477 (population 14), E. gaillardotii had RGS 0.260 , E. normannii 0.560 , and E. phymatosperma between 0.233 (population 2) and 0.235 (population 3; Online Resource 1, Fig. 3).

\section{Morphological and distributional data}

The morphological description of E. normannii (Fig. 4) is provided in the Taxomomic treatment below. As in many

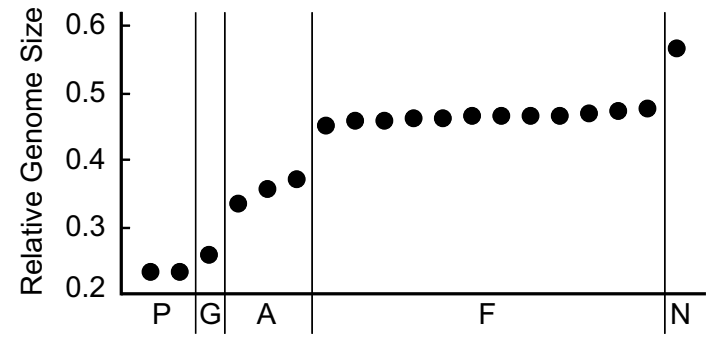

Fig. 3 Mean relative genome size (RGS) of Euphorbia aleppica (A), E. falcata $(\mathrm{F})$, E. gaillardotii $(\mathrm{G})$, E. normannii $(\mathrm{N})$ and $E$. phymatosperma $(\mathrm{P})$

annual Euphorbia species, the general habit of E. normannii is very variable. The stems are sometimes very short, ca. $5 \mathrm{~cm}$ long, and the main part of the plants is formed by the long and branched rays of the synflorescence. Euphorbia normannii clearly differs not only from the perennial species of E. sect. Myrsiniteae, but also from the annual E. aleppica (Online Resource 4). In general habit and other characters, such as the shape of the leaves, it is very similar to $E$. falcata from $E$. sect. Pithyusa, but differs from this species in several other characters (see Table 1, Fig. 5 and Online Resource 4 for details).

The distribution of E. normannii based on available herbarium specimens can be summarised to five localities, four in the southern part of the Stavropol Heights and one from the vicinity of the town of Nevinnomyssk to the south of the Stavropol Heights (Fig. 6; Taxonomic treatment).

\section{Discussion}

Our phylogenetic data show that E. normannii, a regional endemic from the Stavropol Heights area in Russia, has a distinct phylogenetic position within E. subgen. Esula, which, however, differs strongly between the nuclear ITS and the plastid $\operatorname{trn} \mathrm{T}-\operatorname{trn} \mathrm{F}$ sequences. In the ITS phylogenetic tree E. normannii was inferred as sister to the members of E. sect. Myrsiniteae, but shared also some common splits with the members of E. sect. Pithyusa, especially with annual E. falcata, in the NeighborNet (Fig. 1). On the other hand, in the plastid tree (Fig. 2) E. normannii was clearly positioned within E. sect. Pithyusa as sister to most perennial species of the section, which all together formed a polytomy with E. falcata, E. cassia/E. gaillardotii and E. pithyusa. This incongruent phylogenetic placement strongly suggests that E. normannii is of hybrid origin.

Hybridisation, leading to hybrid origin of species, is not a rare phenomenon in plants. It can occur at the homoploid level, i.e. via hybridization not involving whole-genome duplication and thus no increase in ploidy (e.g. Tzvelev 1992; Rieseberg 1997; Frajman et al. 2009; Abbott et al. 

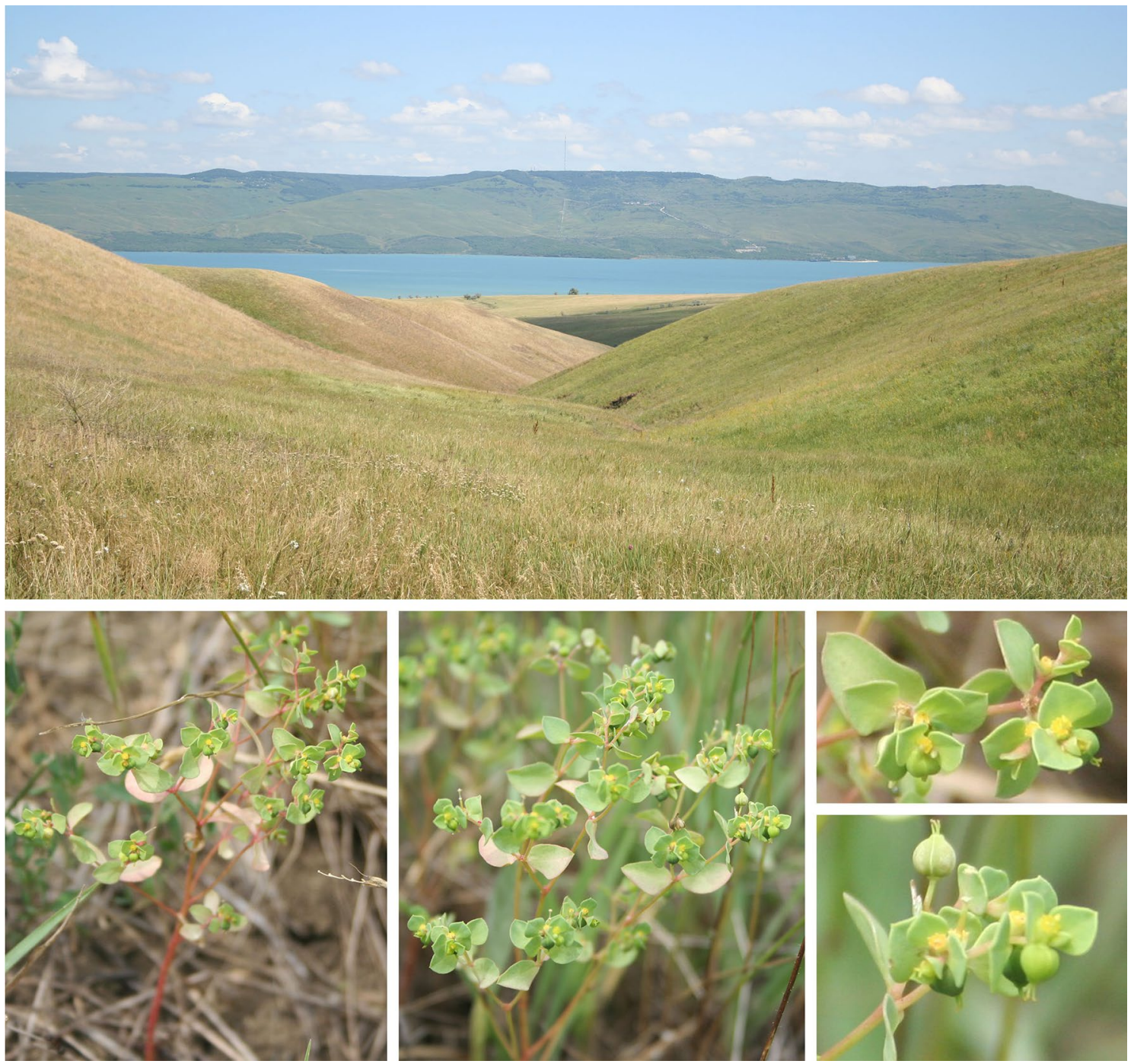

Fig. 4 Typical steppe habitat of Euphorbia normannii near its locus classicus in the Stavropol Heights (above); habit with inflorescence details (below)

2010; Nieto Feliner et al. 2017). More common is allopolyploidisation, accompanied by multiplication of chromosome sets (e.g. Rieseberg 1997; Soltis et al. 2009, 2016; Wood et al. 2009; Husband et al. 2013; Madlung 2013). In combination with plastid DNA sequences, ITS has often been used to infer origins of hybrid plant species (e.g. Sang et al. 1995; Popp et al. 2005; Frajman et al. 2009, 2018; Kuzmanović et al. 2017). However, since the homoeologous ITS repeats in a hybrid often are homogenised towards one of the parental types by concerted evolution (Wendel et al. 1995), the inference of hybrid origin is only possible if the homogenisation is directed towards the paternal lineage (Smedmark and Eriksson 2002; Popp et al. 2005), which was likely the case in E. normannii. A likely annual member of E. sect. Myrsiniteae thus acted as the paternal parent, and an annual member of E. sect. Pithyusa as the maternal parent in the origin of E. normannii.

The distribution area of E. normannii today lies within the distribution of E. sect. Pithyusa. The annual E. falcata as well as the perennial E. glareosa Pall. ex M. Bieb. (sensu stricto, cf. Geltman 2005), E. stepposa Zoz ex Prokh. and E. seguieriana from this section co-occur in the Stavropol Heights, and E. petrophila C.A. Mey. is found in their vicinity. The closest localities of the annual E. gaillardotii are in Asia Minor (Radcliffe-Smith 1982). On the other hand, the nearest localities of members of $E$. sect. Myrsiniteae are at least 200 to $300 \mathrm{~km}$ away, rendering current hybridization in situ impossible. Perennial E. pontica Prokh. and E. rigida M. Bieb. occur in the north-eastern Black Sea coast area, whereas annual E. aleppica has been reported from a few localities in Transcaucasia and 


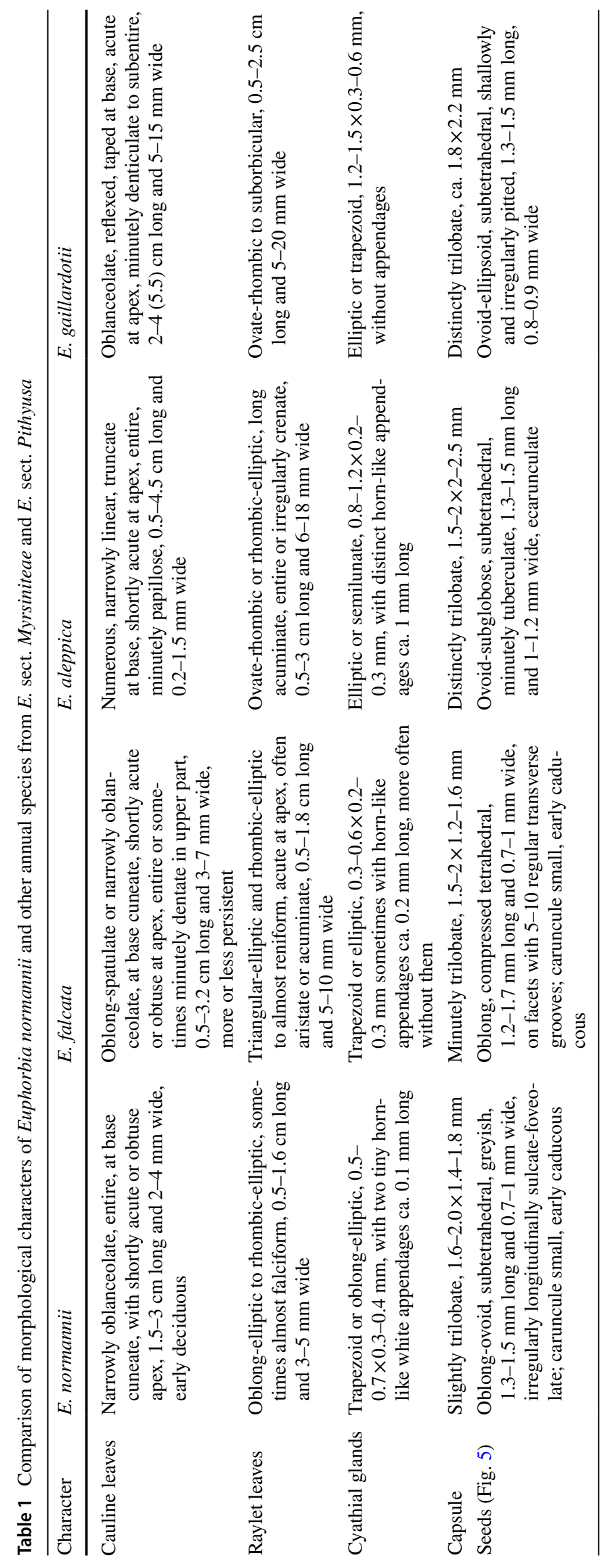


Fig. 5 Seeds of Euphorbia normannii (a), E. falcata (b), E. aleppica (c) and E. gaillardotii (d)
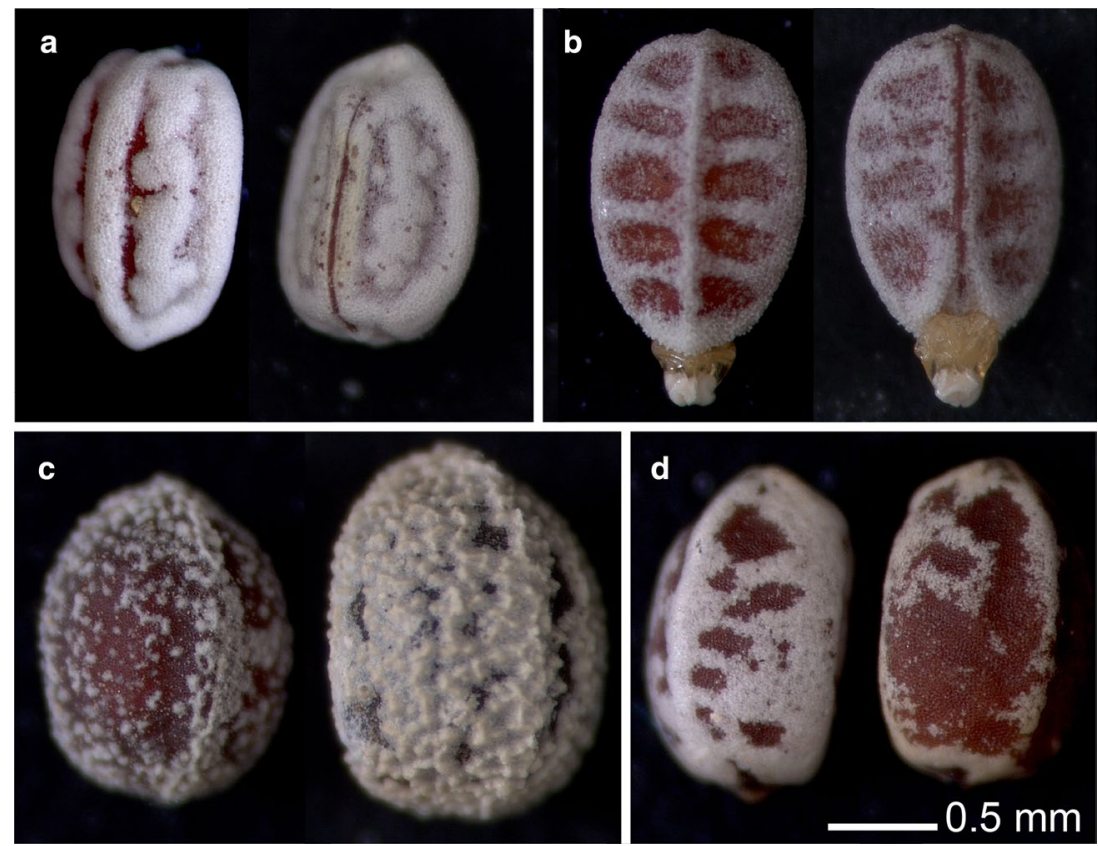

Fig. 6 Distribution of Euphorbia normannii shown on an aerial photography of the Stavropol Heights (adopted from Google Earth); in the inset, the position of the Stavropol Heights in western Eurasia is indicated

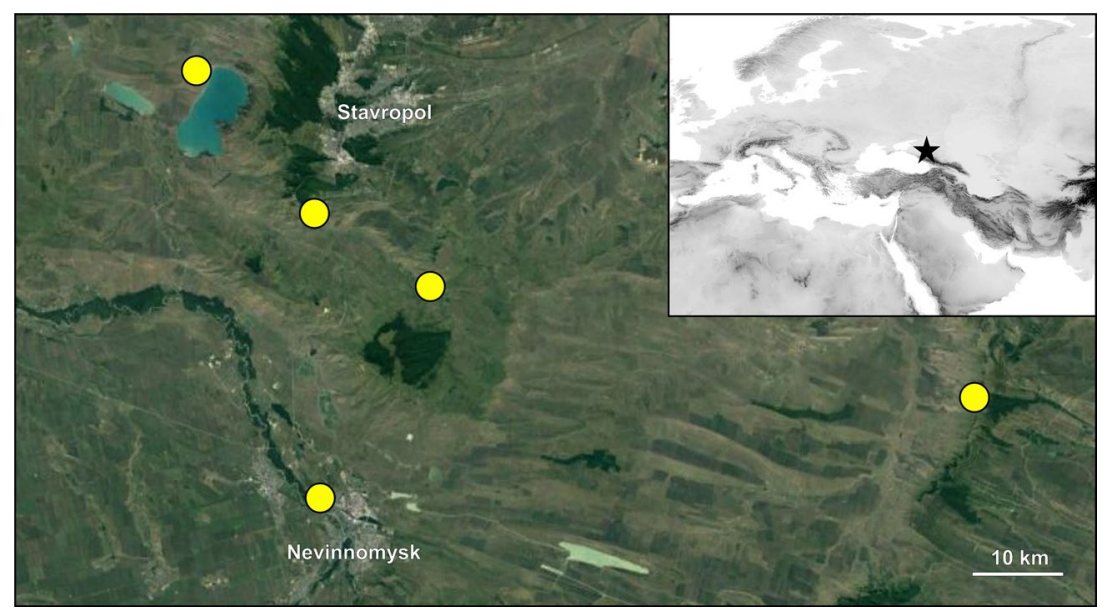

Crimea 400 to $600 \mathrm{~km}$ away. However, it is possible that both sections came in contact in the Stavropol area in the past, since the distribution of species can change through time, which was especially evident during the Pleistocene climatic oscillations and in the face of the Holocene climate warming (e.g. Hewitt 1999; Petit et al. 2003; Magri et al. 2007; Schönswetter et al. 2007). Alternatively, it is either possible that E. normannii originated elsewhere, had a larger distribution in the past and persisted until today only in the Stavropol Heights, or, alternatively, that some other, nowadays extinct, member of the sections Myrsiniteae and/or Pithyusa was involved in its origin.

Based on morphological similarity as well as a close phylogenetic position in the plastid tree and shared common splits in the ITS NeighborNet, we suggest that E. falcata was involved in the origin of or hybridisation with E. normannii. It is unlikely that perennial species would have been involved in hybridisation and origin of E. normannii, as they are morphologically very divergent (see e.g. Frajman and Schönswetter 2017; Frajman et al. 2019). In the case of E. sect. Myrsiniteae, we cannot clearly point to the parental species of E. normannii, given the high morphological dissimilarity of E. aleppica, but inferred phylogeny (Fig. 1) indicates that both annuals diverged early in the evolution of the section and obviously attained very distinct morphology different of that of perennials (see Pahlevani et al. 2011). 
Without establishing the chromosome number and thus the ploidy level of E. normannii, it is also impossible to clearly infer whether it is of homoploid or of allopolyploid hybrid origin. The RGS data suggest that an allopolyploid origin is likely, as E. normannii has the highest RGS of all closely related annual species (Fig. 3). Its RGS is neither the double of that of E. aleppica nor of E. falcata, likely due to genome downsizing accompanying the process of diploidisation following polyploid speciation (Verma and Rees 1974; Leitch and Bennett 2004; Renny-Byfield et al. 2013). For E. aleppica - as well as for all perennial species of $E$. sect. Myrsiniteae - the chromosome number $2 n=20$ has been established, whereas for E. falcata $2 n=14,16,28$, 32,36 and for E. gaillardotii $2 n=18$ have been reported (Rice et al. 2015, and references therein). Given that polyploid, likely tetraploid, individuals have been reported for E. falcata, it appears likely that E. falcata participated also in the allotetraploid origin of $E$. normannii. A scenario alternative to and equally likely as the hybrid origin of $E$. normannii is its non-hybrid origin within E. sect. Myrsiniteae and a later hybridisation with co-occurring $E$. falcata (or any other related, now extinct species), from which E. normannii captured the plastome. Chloroplast capture (Rieseberg and Soltis 1991; Tsitrone et al. 2003) has been proposed as cause of discordant nuclear and plastid phylogenies in several plant groups (e.g. Okuyama et al. 2005; Frajman et al. 2009).

In conclusion, our data indicate that hybridisation was involved in the evolutionary history of E. normannii, a stenoendemic species of the Stavropol Heights in Russia, highlighting the importance of the Caucasus as an important biodiversity hotspot and centre of plant endemism. In particular, it emphasises a high conservation value of the Stavropol Heights, a small area harbouring six endemic angiosperms.

\section{Taxonomic treatment}

Based on the incongruent phylogenetic position of E. normannii across plastid and nuclear phylogenies, we could include this species both in E. sect. Myrsiniteae and in $E$. sect. Pithyusa. The absence of bracteoles subtending the male flowers is one of the main synapomorphies of $E$. sect. Myrsiniteae (Riina et al. 2013). However, in the cyathia of E. normannii we found filiform structures, which are very likely the bracteoles of male flowers. This, along with the similarity in habit of $E$. normannii with $E$. falcata, we propose its inclusion in $E$. sect. Pithyusa. We emphasise the importance of future studies of the internal cyathial structures and their ontogenetic development in $E$. subgen. Esula, along with the evaluation of their taxonomic value.
Euphorbia normannii Schmalh. ex Lipsky in Zap. Kievsk. Obshch. Estestvoisp. 11(2): 57. 1891. ETithymalus normannii (Schmalh. ex Lipsky) Prokh., in Komarov, Fl. URSS, 14: 466, nom. alt.—LECTOTYPE (designated by Geltman 2000: 103): [Russia, Stavropol Territory], Rybnoe Lake, 17 May 1879, 6 Jun 1883, Normann s.n. (KW!).

Description: Glabrous or rarely shortly pubescent annual 10-30 cm high, with solitary, erect or sometimes ascendent stem 5-10 cm high and 0.3-1.5(1.8) mm thick, arising from a vertical root, usually without axillary vegetative shoots. Axillary rays 2-8, 2-12(15) cm long, 1-3(4)-times dichotomous. Cauline leaves with 3 palmate veins, narrowly oblanceolate, entire, at base cuneate, with shortly acute or obtuse apex, $1.5-3 \mathrm{~cm}$ long and $2-4 \mathrm{~mm}$ wide, early deciduous. Ray leaves similar to the cauline leaves. Terminal rays $2-4,2.5-6 \mathrm{~cm}$ long, 1-3 times dichotomous. Raylet leaves oblong-elliptic to rhombic-elliptic, sometimes almost falciform, $0.5-1.6 \mathrm{~cm}$ long and 3-5 mm wide. Cyathium campanulate, ca. $1 \times 0.5 \mathrm{~mm}$. Bracteoles of male flowers filiform. Cyathial glands trapezoid or oblong-elliptic, $0.5-0.7 \times 0.3-0.4 \mathrm{~mm}$, with two tiny hornlike white appendages ca. $0.1 \mathrm{~mm}$ long. Capsule broadly conical, slightly trilobate, $1.6-2.0 \times 1.4-1.8 \mathrm{~mm}$. Styles free, ca. $0.5 \mathrm{~mm}$. Seeds oblong-ovoid, subtetrahedral, greyish, $1.3-1.5 \mathrm{~mm}$ long and $0.7-1 \mathrm{~mm}$ wide, irregularly longitudinally sulcate-foveolate. Caruncle conical $0.2-0.3 \mathrm{~mm}$, early deciduous, and therefore seeds often appear ecarunculate.

Habitat: Steppes, usually on unstable, moving soil, or open steppe areas with sparse plant cover (Fig. 4). Sometimes growing together with E. falcata.

Distribution: Known from four localities in the southern part of the Stavropol Heights (vicinity of village Tatarka, village of Temnolesskaya, Lake Rybnoe-Sengileevskoe reservoir, Prikalaus Hills close to Aleksandrovskoe) and from the vicinity of the town of Nevinnomyssk south of the Stavropol Heights (Fig. 6).

Conservation status: Following criterion D for vulnerable species of the IUCN (2012) Red List categories, i.e. population size estimated to number fewer than 1000 mature individuals with a very restricted area of occupancy, we deem E. normannii vulnerable (VU) based on the current knowledge of its distribution.

Additional specimens studied: Russia, Stavropol Territory: Shpakovsky District, vicinity of Tatarka, $44^{\circ} 55^{\prime} 46.3^{\prime \prime} \mathrm{N}$, $41^{\circ} 54^{\prime} 30.1^{\prime \prime} \mathrm{E}$, slope of small depression amongst steppe vegetation, plot with sparse herb cover, $321 \mathrm{~m}$ a. s. $1 ., 19$ Jun 2015, Geltman 235 (LE 01057241, 01057242); south of 
Tatarka (vicinity of Stavropol), valley of the river Egorlyk, on slope, 7 Aug 1949, I.V. Novopokrovsky, A.I. Pojarkova 296, $296 a$ (LE 01057243, 01057247); In vicinia opp. Stauropolis, ripa lacus Sengilejevski (v. Rybnoje), in glareosis, 28 Jul 1949, E. Bobrov, Ja. Prokhanov s.n. (LE 01057244, 01057245 MW 0690362); Kuban province, Nevinnomysskaya, close to the camp near the river Kuban, 26 Jun 1890, V. Lipsky s.n. (LE 01057246); Nevinnomysskaya, along the river Kuban, 3 Jun 1892, V. Lipsky s.n. (LE 01057248 01057253); Nevinnomysskaya, Rychev hill, 9 Jul 1932, [V.A. Arsenyev] s.n. (MW 0690361); Temnolesskaya, 2000' 17 Jun 1889, I.Ya. Akinfiev s.n. (LE 01057254, 01057255); Prikalaus Heights, 12-15 km NWW from Aleksandrovskoye, Artemisia - Festuca valesiaca steppes on slightly saline slopes and bottoms of a ravine, 29 Jun 1988, Geltman et al. 2050 (LE 01057256).

\section{Information on Electronic Supplementary Mate- rial}

Online Resource 1. Studied populations of Euphorbia normannii and related Euphorbia species, including voucher information, GenBank numbers and relative genome size (RGS) data.

Online Resource 2. Alignment of ITS sequences used in this study. Accession names are complemented with GenBank numbers and their voucher data available in Online Resource 1.

Online Resource 3. Alignment of plastid $\operatorname{trn} \mathrm{T}-\operatorname{trn} \mathrm{F}$ sequences used in this study. Accession names are complemented with GenBank numbers and their voucher data available in Online Resource 1.

Online Resource 4. Herbarium specimens of Euphorbia aleppica, E falcata, E gaillardotii and E normannii (all deposited at LE), showing morphological differences among the species.

Supplementary Information The online version of this article (https:// doi.org/10.1007/s00606-021-01741-8) contains supplementary material, which is available to authorized users.

Acknowledgements This study was financially supported by the Knoll Foundation of the Austrian Academy of Sciences (ÖAW, to B.F.) and by an institutional research project of the Komarov Botanical Institute (N AAAA-A19-1190312900521-1, to D.G.). We thank all collectors listed in Online Resource 1. D. Pirkebner, L. Silbernagl and P. Bartolić helped with laboratory work, L. Silbernagl with production of Fig. 6, K. Demchenko took photographs for Fig. 5 and M.V. Legczenko for Online Resource 4. RGS was measured by the students $\mathrm{V}$. Als, A. Dudaš, V. Engl, D. Patsch, D. Scheerer, V. Steinkasserer and V. Stojilković. The research was partly performed using equipment of the Core Facilities Centre "Cell and Molecular Technologies in Plant Science" at the Komarov Botanical Institute RAS (St.-Petersburg, Russia). We thank three reviewers for their comments.

Authors' contributions Optional: please review the submission guidelines from the journal whether statements are mandatory.
Funding Open Access funding provided by University of Innsbruck and Medical University of Innsbruck. This study was financially supported by the Knoll Foundation of the Austrian Academy of Sciences (ÖAW, to B.F.) and by an institutional research project of the Komarov Botanical Institute (N AAAA-A19-1190312900521-1, to D.G.).

\section{Compliance with ethical standards}

Conflict of interest There is no conflict of interests.

Ethics approval Ethical approval does not apply. Accepted principles of ethical and professional conduct have been followed.

Consent to participate No consent to participate is needed.

Consent for publication No consent for publication is needed.

Availability of data and material Data are available as Electronic Supplementary Material. Sequences have been submitted to GenBank.

Code availability No specific software application or custom code was generated.

Open Access This article is licensed under a Creative Commons Attribution 4.0 International License, which permits use, sharing, adaptation, distribution and reproduction in any medium or format, as long as you give appropriate credit to the original author(s) and the source, provide a link to the Creative Commons licence, and indicate if changes were made. The images or other third party material in this article are included in the article's Creative Commons licence, unless indicated otherwise in a credit line to the material. If material is not included in the article's Creative Commons licence and your intended use is not permitted by statutory regulation or exceeds the permitted use, you will need to obtain permission directly from the copyright holder. To view a copy of this licence, visit http://creativecommons.org/licenses/by/4.0/.

\section{References}

Abbott RJ, Hegarty MJ, Hiscock SJ, Brennan AC (2010) Homoploid hybrid speciation in action. Taxon 59:1375-1386. https://doi. org/10.1002/tax.595005

Cresti L, Schönswetter P, Peruzzi L, Barfuss MHJ, Frajman B (2019) Pleistocene survival in three Mediterranean refugia: origin and diversification of the Italian endemic Euphorbia gasparrinii from the E. verrucosa alliance (Euphorbiaceae). Bot J Linn Soc 189:262-280. https://doi.org/10.1093/botlinnean/boy082

Falch M, Schönswetter P, Frajman B (2019) Both vicariance and dispersal have shaped the genetic structure of Eastern Mediterranean Euphorbia myrsinites (Euphorbiaceae). Perspect Pl Ecol Evol Syst 39:125459. https://doi.org/10.1016/j.ppees.2019.125459

Frajman B, Záveská E, Gamisch A, Moser T, The STEPPE Consortium, Schönswetter P (2019) Integrating phylogenomics, phylogenetics, morphometrics, relative genome size and ecological niche modelling disentangles the diversification of Eurasian Euphorbia seguieriana s. 1. (Euphorbiaceae). Molec Phylogen Evol 134: 238-252. https://doi.org/10.1016/j.ympev.2018.10.046

Frajman B, Schönswetter P (2011) Giants and dwarfs: molecular phylogenies reveal multiple origins of annual spurges within 
Euphorbia subg. Esula. Molec Phylogen Evol 61:413-424. https ://doi.org/10.1016/j.ympev.2011.06.011

Frajman B, Schönswetter P (2017) Amphi-Adriatic distributions in plants revisited: pleistocene trans-Adriatic dispersal in the Euphorbia barrelieri group (Euphorbiaceae). Bot J Linn Soc 185:240-252. https://doi.org/10.1093/botlinnean/box055

Frajman B, Eggens F, Oxelman B (2009) Hybrid origins and homoploid reticulate evolution within Heliosperma (Sileneae, Caryophyllaceae) — a multigene phylogenetic approach with relative dating. Syst Biol 58:328-345. https://doi.org/10.1093/sysbi o/syp030

Frajman B, Schönswetter P, Weiss-Schneeweiss H, Oxelman B (2018) Origin and diversification of South American polyploid Silene sect. Physolychnis (Caryophyllaceae) in the Andes and Patagonia. Frontiers Genet 9:639. https://doi.org/10.3389/fgene.2018.00639

Geltman DV (2000) Rod Euphorbia (Euphorbiaceae) vo flore Kryma, Kavkaza i Maloy Azii. I. Sektsiya Peplus Lázaro [Genus Euphorbia (Euphorbiaceae) in the flora of Crimea, Caucasus and Asia Minor. I. Section Peplus Lázaro]. Novosti Sist Vyssh Rast 32:96-108

Geltman DV (2005) Rod Euphorbia (Euphorbiaceae) vo flore Kryma, Kavkaza i Maloy Azii. I. Sektsiya Paralias Dumort. [Genus Euphorbia (Euphorbiaceae) in the flora of Crimea, Caucasus and Asia Minor. I. Section Paralias Dumort]. Novosti Sist Vyssh Rast 37:134-151

Geltman DV (2015) Phytogeographical analysis of Euphorbia subgenus Esula (Euphorbiaceae). Polish Bot J 60:147-161. https://doi. org/10.1515/pbj-2015-0024

Hewitt GM (1999) Post-glacial re-colonisation of European biota. Biol J Linn Soc 68:87-112. https://doi.org/10.1006/bijl.1999.0332

Husband BC, Baldwin SJ, Suda J (2013) The incidence of polyploidy in natural plant populations: major patterns and evolutionary processes. In: Leitch IJ, Greilhuber J, Doležel J, Wendel JF (eds) Plant Genome Diversity, vol. 2. Springer. New York, USA, pp 255-276

Huson DH, Bryant D (2006) Application of phylogenetic networks in evolutionary studies. Molec Biol Evol 23:254-267. https://doi. org/10.1093/molbev/msj030

IUCN (2012) IUCN Red List categories and criteria: Version 3.1, 2nd edition. Gland, Switzerland and Cambridge: IUCN. Available at: http://www.iucnredlist.org. Accessed 6 May 2020

Ivanov AL, Ivanov AA, Chimonina IV (2010) Endemiki i relikty Stavropolskoy vozvyshennosti i ikh znacheniye dlya postoeniya modeli florogeneza tsentralnoy chasti Severnogo Kavkaza [Endemics and relicts of Stavropol Heights and their significance for the development of the model of florogenesis of the central part of the Northern Caucasus]. Stavropol State University Publishing, Stavropol

Kearse M, Moir R, Wilson A, Stones-Havas S, Cheung M, Sturrock S, Buxton S, Cooper A, Markowitz S, Duran C, Thierer T, Ashton B, Meintjes P, Drummond A (2012) Geneious basic: an integrated and extendable desktop software platform for the organization and analysis of sequence data. Bioinformatics 28:1647-1649. https:// doi.org/10.1093/bioinformatics/bts199

Kuzmanović N, Lakušić D, Frajman B, Alegro A, Schönswetter P (2017) Phylogenetic relationships in Seslerieae (Poaceae) including resurrection of Psilathera and Sesleriella, two monotypic genera endemic to the Alps. Taxon 66:1349-1370. https:// doi.org/10.12705/666.5

Leitch IJ, Bennett MD (2004) Genome downsizing in polyploid plants. Biol J Linn Soc 82:651-663. https://doi.org/10.111 $1 /$ j.1095-8312.2004.00349.x

Lipsky VI (1891) Issledovaniye Severnogo Kavkaza (1889-90) [Study of the Northern Caucasus]. Zap Kievsk Obshch Estestvoisp 11:23-62
Madlung A (2013) Polyploidy and its effect on evolutionary success: old questions revisited with new tools. Heredity 110:99-104. https://doi.org/10.1038/hdy.2012.79

Magri D, Vendramin GG, Comps B, Dupanloup I, Geburek T, Gömöry D, Latalowa M, Litt T, Paule L, Roure JM, Tantau I, van der Knapp WO, Petit RJ, Beaulieu JL (2006) A new scenario for the Quaternary history of European beech populations: palaeobotanical evidence and genetic consequences. New Phytol 171:199-221. https://doi.org/10.1111/j.1469-8137.2006.01740 .x

Menitsky YL (2004) Oaks of Asia. Translated from Russian. Amerind Publishing, New Delhi

Mittermeier R, Robles GP, Hoffman M, Pilgrim J, Brooks T, Gill PR, Mittermeier CG, Lamoreux J (2005) Hotspots revisited: Earth's biologically richest and most endangered terrestrial ecoregions. Conservation International, Washington

Myers N, Mittermeier RA, Mittermeier CG, Da Fonseca GA, Kent J (2000) Biodiversity hotspots for conservation priorities. Nature 403:853-858. https://doi.org/10.1038/35002501

Nieto Feliner G, Álvarez I, Fuertes-Aguilar J, Heuertz M, Marques I, Moharrek F, Piñeiro R, Riina R, Rosselló JA, Soltis PS, VillaMachío I (2017) Is homoploid hybrid speciation that rare? An empiricist's view. Heredity 118:513-516. https://doi.org/10.1038/ hdy. 2017.7

Nylander JAA (2004) MrAIC. pl. 1.4. 3. Program distributed by the author

Okuyama Y, Fujii N, Wakabayashi M, Kawakita A, Ito M, Watanabe M, Murakami N, Makoto K (2005) Nonuniform concerted evolution and chloroplast capture: heterogeneity of observed introgression patterns in three molecular data partition phylogenies of Asian Mitella (Saxifragaceae). Molec Biol Evol 22:285-296

Pahlevani A, Geltman DV, Riina R (2011) Taxonomic Revision of Euphorbia subsect. Myrsiniteae in Iran. Ann Bot Fenn 48:483493. https://doi.org/10.5735/085.048.0606

Panina LV (2009) Noveishyi strukturnyi risunok Skifskoi plity [The newest picture of the Sciphean plate]. Vest Moskov Univ, Ser 4 Geol 1:23-31

Petit RJ, Aguinagalde I, De Beaulieu JL, Bittkau C, Brewer S, Cheddadi R, Ennos R, Fineschi S, Grivet D, Lascoux M, Mohanty A, Muller-Starck G, Demesure-Musch B, Palme A, Martin JP, Rendell S, Vendramin GG (2003) Glacial refugia: hotspots but not melting pots of genetic diversity. Science 300:1563-1565. https:// doi.org/10.1126/science.1083264

Popov SV, Rögl F, Rozanov AY, Steninger FF, Shcherba IG, Kovac M (eds) (2004) Lithological-Paleogeographic maps of Paratethys. Courier Forschungsinst Senckenberg 250:1-46

Popp M, Erixon P, Eggens F, Oxelman B (2005) Origin and evolution of a circumpolar polyploid species complex in Silene (Caryophyllaceae) inferred from low copy nuclear RNA Polymerase introns, rDNA, and chloroplast DNA. Syst Bot 30:302-313. https://doi. org/10.1600/0363644054223648

Prokhanov YI (1949) Rod molochay-Euphorbia L. [Spurge genusEuphorbia L.]. In: Komarov VL (ed) Flora URSS 14. Moscow \& Leningrad, Izdatelstvo Akademii nauk SSSR, pp 304-395

Prokhanov YI (1964) Konspekt sistemy molochaev SSSR. Dopolneniya i izmeneniya [Conspectus of the spurges system for the USSR. Additions and corrections]. Novosti Sist Vyssh Rast 1: 226-237

Radcliffe-Smith A (1982) Euphorbia L. In: Davis PH (ed) Flora of Turkey and the East Aegean Islands 7. Edinburgh University Press, Edinburgh, pp 571-630

Renny-Byfield S, Kovarik A, Kelly LJ, Macas J, Novak P, Chase MW, Nichols RA, Pancholi MR, Grandbastien MA, Leitch AR (2013) Diploidization and genome size change in allopolyploids is associated with differential dynamics of low- and high-copy sequences. Pl J 74:829-839. https://doi.org/10.1111/tpj.12168 
Rice A, Glick L, Abadi S, Einhorn M, Kopelman NM, Salman-Minkov A, Mayzel J, Chay O, Mayrose I (2015) The Chromosome Counts Database (CCDB) - a community resource of plant chromosome numbers. New Phytol 206:19-26. https://doi.org/10.1111/ nph.13191

Rieseberg LH (1997) Hybrid origins of plant species. Annual Rev Ecol Syst 28:359-389. https://doi.org/10.1146/annurev.ecols ys.28.1.359

Rieseberg LH, Soltis DE (1991) Phylogenetic consequences of cytoplasmic gene flow in plants. In: Takhtajan A (ed) Evolutionary Trends in Flowering Plants. Columbia University Press, New York

Riina R, Peirson JA, Geltman DV, Molero J, Frajman B, Pahlevani A, Barres L, Morawetz JJ, Salmaki Y, Zarre S, Kryukov A, Bruyns PV, Berry PE (2013) A worldwide molecular phylogeny and classification of the leafy spurges, Euphorbia subgenus Esula (Euphorbiaceae). Taxon 62:316-342. https://doi.org/10.12705 1622.3

Ronquist F, Teslenko M, Van Der Mark P, Ayres DL, Darling A, Höhna S, Larget B, Liu L, Suchard MA, Huelsenbeck JP (2012) MrBayes 3.2: efficient bayesian phylogenetic inference and model choice across a large model space. Syst Biol 61:539-542. https://doi. org/10.1093/sysbio/sys029

Sang T, Crawford DJ, Stuessy TF (1995) Documentation of reticulate evolution in peonies (Paeonia) using internal transcribed spacer sequences of nuclear ribosomal DNA: implications for biogeography and concerted evolution. Proc Natl Acad Sci USA 92:68136817. https://doi.org/10.1073/pnas.92.15.6813

Schmalhausen I (1892) Neue Pflanzenarten aus dem Kaukasus. Ber Deutsch Bot Ges 10:284-294

Schönswetter P, Suda J, Popp M, Weiss-Schneeweiss H, Brochmann C (2007) Circumpolar phylogeography of Juncus biglumis (Juncaceae) inferred from AFLP fingerprints, cpDNA sequences, nuclear DNA content and chromosome numbers. Molec Phylogen Evol 42:92-103. https://doi.org/10.1016/j.ympev.2006.06.016

Smedmark JEE, Eriksson T (2002) Phylogenetic relationships of Geum (Rosaceae) and relatives inferred from the nrITS and $\operatorname{trnL}$-trnF regions. Syst Bot 27:303-317. https://doi. org/10.1043/0363-6445-27.2.303

Solomon JC, Shulkina T, Schatz GE (eds) (2014) Red list of the endemic plants of the Caucasus: Armenia, Azerbaijan, Georgia,
Iran, Russia, and Turkey. Missouri Botanical Garden Press, Saint Louis, $\mathrm{p} 451$

Soltis DE, Albert VA, Leebens-Mack J, Bell CD, Paterson AH, Zheng C, Sankoff D, Depamphilis CW, Wall PK, Soltis PS (2009) Polyploidy and angiosperm diversification. Amer J Bot 96:336-348. https://doi.org/10.3732/ajb.0800079

Soltis DE, Visger CJ, Marchant DB, Soltis PS (2016) Polyploidy: pitfalls and paths to a paradigm. Amer J Bot 103:1146-1166. https ://doi.org/10.3732/ajb.1500501

Suda J, Trávníček P (2006) Estimation of relative nuclear DNA content in dehydrated plant tissues by flow cytometry. Curr Protoc Cytom 7:30. https://doi.org/10.1002/0471142956.cy0730s38

Swofford DL (2002) Phylogenetic analysis using parsimony. Sinauer Associate, Sunderland

Tsitrone A, Kirkpatrick M, Levin DA (2003) A model for chloroplast capture. Evolution 57:1776-1782. https://doi. org/10.1111/j.0014-3820.2003.tb00585.x

Tzvelev NN (1992) Gibridizatsiya kak odin iz faktorov uvelicheniya biologicheskogo raznoobraziya i genomnyi kriterii rodov u vysshykh rastenii [Hybridization as one of factors of the increase of biological diversity and the genomic criterion of genera in higher plants]. In: Yurtsev BA (ed) Biologichskoe raznoobrazie: podkhody $\mathrm{k}$ izucheniyu i sokhraneniyu [Biological diversity: approaches to investigation and conservation]. Zoological Institute of the Russian Academy of Sciences, St. Petersburg, pp 193-201

Verma SC, Rees H (1974) Nuclear DNA and evolution of allotetraploid Brassicaceae. Heredity 33:61-68. https://doi.org/10.1038/ hdy. 1974.64

Wendel JF, Schnabel A, Seelanan T (1995) Bidirectional interlocus concerted evolution following allopolyploid speciation in cotton (Gossypium). Proc Natl Acad Sci USA 92:280-284. https://doi. org/10.1073/pnas.92.1.280

Wood TE, Takebayashi N, Barker MS, Mayrose I, Greenspoon PB, Rieseberg LH (2009) The frequency of polyploid speciation in vascular plants. Proc Natl Acad Sci USA 106:13875-13879. https ://doi.org/10.1073/pnas.0811575106

Publisher's Note Springer Nature remains neutral with regard to jurisdictional claims in published maps and institutional affiliations. 